\title{
Bibliometric Analysis of Zakat Research in Scopus Database
}

\author{
Siti Maziah Ab Rahman, Khalid Abdul Wahid, Mohd Noor Azam Nafi, Suryani \\ Awang, Mariam Setapa \\ Universiti Teknologi MARA Cawangan Kelantan
}

Muhsin Nor Paizin

Akademi Zakat (AZKA), Pusat Pungutan Zakat (PPZ-MAIWP)

\begin{abstract}
Scopus research paper on the zakat was systematically analyzed using the VOSviewer bibliometric measurement. A total of 492 citation data was exported from Scopus on the query of zakat, and from the initial result, twelve journals were selected in the expanded query process. The journals are Journal of Islamic Accounting and Business Research, International Journal of Islamic and Middle Eastern Finance and Management, International Journal of Innovation Creativity and Change, Advanced Science Letters, and Iop Conference Series Earth and Environmental Science were selected in the query expansion and exported for data visualization in VOSviewer. Results from the journal query returned 492 documents specializing in research of zakat payment. Co-word or co-occurrence analysis was used to identify key themes, and potential future research direction was highlighted.
\end{abstract}

Keywords: Zakat research, bibliometric, research journal, co-word analysis, Scopus, VOSviewer

\section{INTRODUCTION}

This research explored research papers from the Scopus database, specifically research journal articles on zakat. The search query in Scopus was refined and intended to focus on elements of usage in zakat. Twelve high impact journals were chosen from the results, and journal ranking is shown in Table 1 below. The objective of this study is to identify apparent research themes and to forecast future research direction based on Scopus citation data analysis. Frequently used key terms in Zakat research are computed in VOSviewer software, which visualizes the sciences behind the Zakat research topics.

Scholars communicate, collaborate, and converse in a variety of channels. They present papers in conferences, exchange data, the proposed model, identify problems, and mostly nowadays, their communication is in the form of citations. Bibliometrics is the study of documents and citationbased measures applied most commonly to journals, also measures articles, authors, and institutions (RoldanValadez, Salazar-Ruiz, IbarraContreras, \& Rios, 2018). In the context of quantitative research, bibliometric is the statistical analysis method on evaluating research outputs, importance, and influence of authors, institutes, journals, etc., within a certain field (Elisabetta et al., 2019; Geng et al., 2017).

According to Brahaj et al. (2013), research on zakat has been reviewed for many years as an avenue of extensive research and practical 
implementations. It is one of the established and the third pillar of Islam which is stipulated and fixed with the main function to save recipient from involving in crimes and other unhealthy activities, thus, enabling social security and harmony among people on the society (Yusuf et al. (2020). Despite the wide-ranging developments, the term "Zakat" remains ambiguous and varies between different communities. Part of the ambiguity originates from the shared perceptions related to the concepts "Zakat," but this has not spared the specialists who, approaching the problem from different backgrounds, bring their own conceptualization of zakat in a different environment. According to (Rahim \& Kaswadi, 2014), the term zakat has three different connotations. Linguistically, this means cleaning or purifying something. Besides, zakat is defined as "that portion of a man's wealth designated for the poor," said (Azeez, 2003). The scholar of Islam defined zakat as part of the property with certain requirements that Allah SWT requires the proprietor to give to the appropriate person to have it with certain needs (Hassan, 2007).

Table 1. Journal Ranking, SJR and Scopus Citescore

\begin{tabular}{lcc}
\hline \multicolumn{1}{c}{ Journal Title } & SJR & CiteScore \\
\hline Journal of Islamic Accounting and Business Research & $0.372 / \mathrm{Q} 1$ & 1.8 \\
International Journal of Islamic and Middle Eastern Finance & $0.286 / \mathrm{Q} 1$ & 1.9 \\
and Management & & \\
International Journal of Innovation Creativity and Change & $0.225 / \mathrm{Q} 1$ & 0.5 \\
Advanced Science Letters & $0.126 / \mathrm{Q} 1$ & 0.4 \\
Iop Conference Series Earth and Environmental Science & $0.175 / \mathrm{Q} 1$ & 0.4 \\
\hline
\end{tabular}

\section{METHODOLOGY}

Scopus database was queried with the following code (TITLE-ABS-KEY ("Zakat")) which returned 493 documents. The retrieval was done on $8^{\text {th }}$ August 2020, and the result will be most likely to increase over time. Coword or co-occurrence of key terms was analyzed using VOSviewer software. Query expansion (QE) was used on data collection with the objective of refining the retrieved literature based on the operational definition. Twelve highimpact journals were selected based on the relevancy to the operational definition, and the co-occurrence of keywords was also performed.

The research aims to explore the sciences behind Zakat research in the context of its usage. Elements of significant usage such as media (printed book vs. e-book), usage statistics, log analysis, database systems, and elearning are sought in the co-word analysis. In the $\mathrm{QE}$ process, the following search string was used, (TITLE-ABS-KEY ("Zakat") AND (usage) AND (LIMIT-TO (EXACTSRCTITLE, "Journal of Islamic Accounting and Business Research") OR LIMIT-TO (EXACTSRCTITLE, "International Journal of Islamic and Middle Eastern Finance and Management") OR LIMIT-TO (EXACTSRCTITLE, "International Journal of Innovation Creativity and Change") OR LIMITTO (EXACTSRCTITLE , "Advanced Science Letters") OR LIMIT-TO (EXACTSRCTITLE, "Zakat Philosophy And Practice") OR LIMIT- 
TO (EXACTSRCTITLE, "Iop Conference Series Earth and Environmental Science").

\section{RESEARCH RESULT}

In terms of documents by year, research on zakat has been, on average, 100 papers per year from 2000 to 2021, as shown in Figure 1 below. The documents with the highest documents by year are from the year 2019, which is
94 documents. Meanwhile, the secondhighest came from the year 2017 and 2018, which is 61 documents. For the third-highest are came from the current year 2020, which is 57 documents. In addition, for the fourth-highest are from the year 2016, which is 38 documents, and for the fifth are from the year 2014, which is 35 documents. Besides that, the other documents have not more than 30 documents between the year 2000 until 2013.

Documents by year

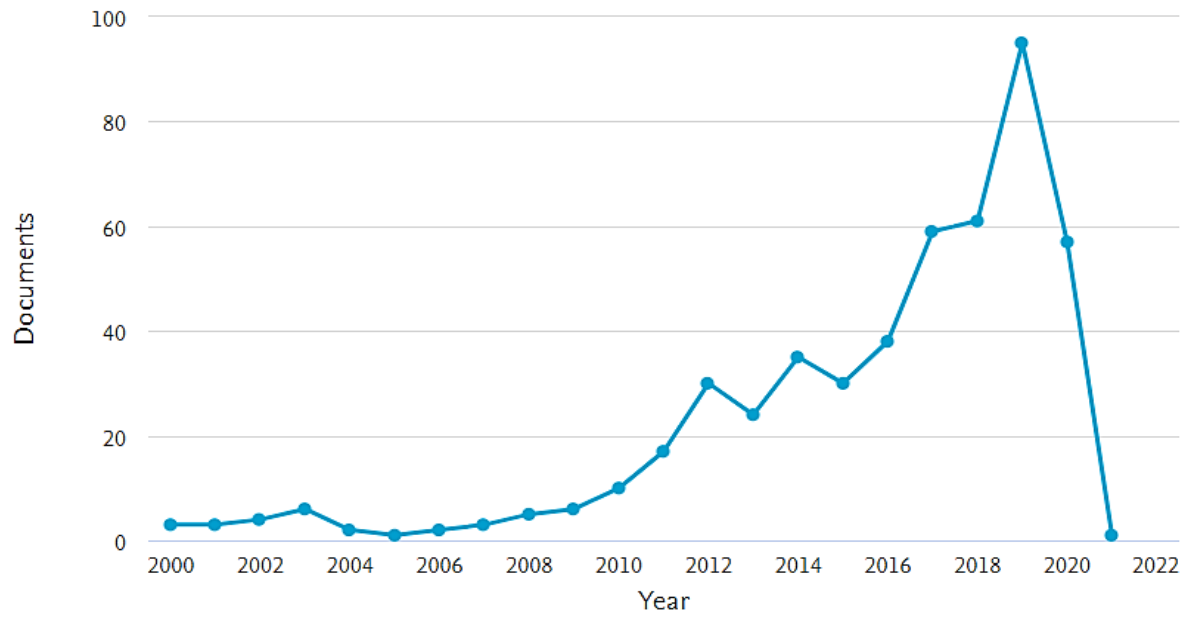

Figure 1. Screenshot of Scopus Document by Year

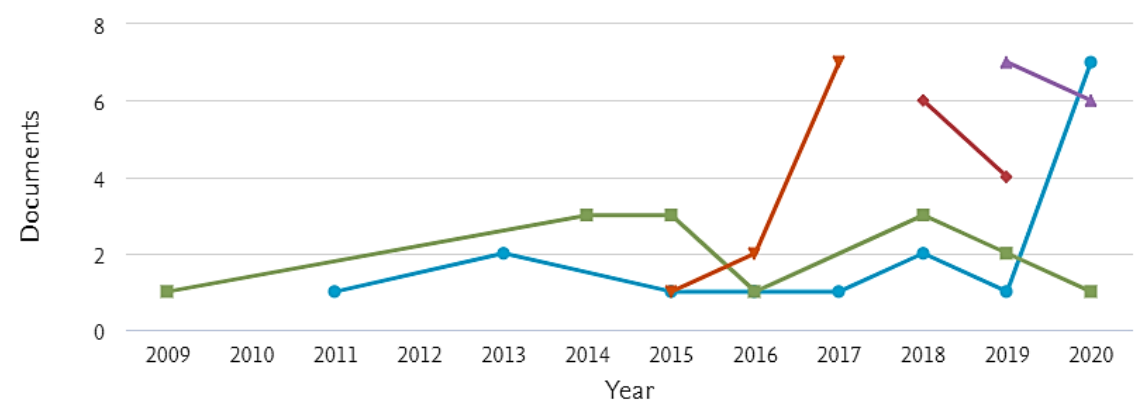

- Journal Of Islamic Accounting And Business Research

$\rightarrow$ lop Conference Series Earth And Environmental Science

- International Journal Of Islamic And Middle Eastern Finance And Management

- International Journal Of Innovation Creativity And Change $\quad$ * Advanced Science Letters

Figure 2. Screenshot of Scopus Documents per Year by Sources 
The graph shows the documents per year by sources from 2009 to 2020 , as shown in Figure 2 below. If we looked at the trends over time, it could see that the highest documents per year by sources are from the Journal of Islamic Accounting and Business Research, which is 16 documents and comes from the year 2011 to 2020. Scopus coverage years from 2010 to Present. Next, the second-highest from the International Journal of Islamic and Middle Eastern Finance and Management, which is 14 documents and came from the year 2009 to 2020.Scopus coverage years from 2008 to Present.
Meanwhile, the third-highest is from the International Journal of Innovation, Creativity, and Change, which are 13 documents and came from the year 2019 to 2020. Scopus coverage years from 2013 to present. In addition, for the fourth-highest are from Advanced Science Letters and Iop Conference Series Earth and Environmental Science, which are ten documents. For Advanced Science Letters came from the year 2015 to 2017; meanwhile, Iop Conference Series Earth and Environmental Science came from 2018 to 2019. Scopus coverage years for Scopus coverage years are from 2010 to 2017 and from 2010 to Present.

Documents by author

Compare the document counts for up to 15 authors.

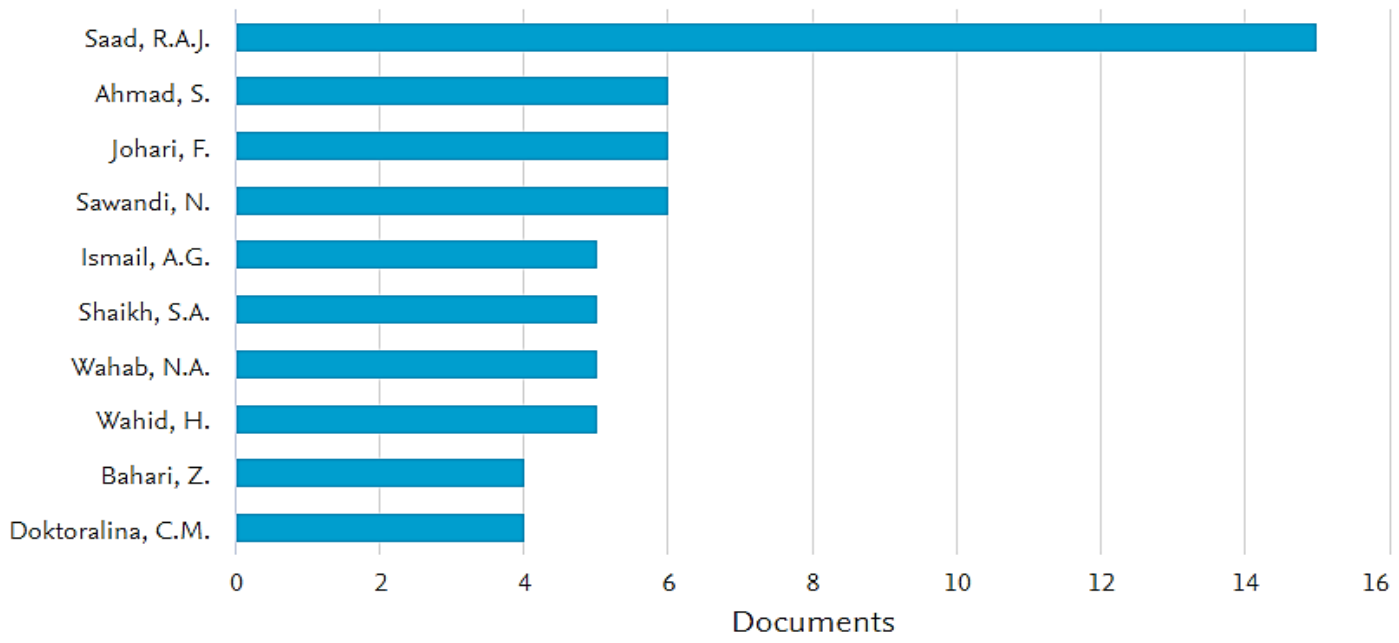

Figure 3. Screenshot of Scopus Documents by Authors.

The graph shows the documents by authors, as shown in Figure 3 below. The highest documents by authors are from Ram Al Jaffri Saad with 15 documents in the collected data, as shown in Figure 3. Next, the secondhighest from three authors which are Sanep Ahmad, Fuadah Binti Johari, and Norfaiezah Sawandi, with six documents. Meanwhile, the thirdhighest is also from three authors which are Abdul Ghafar Ismail, Salman Ahmed Shaikh, and Hairunnizam Wahid, with five documents. Lastly, for the fourth-highest are from two authors which are Zakaria Bahari and Caturida Meiwanto Doktoralina, with four documents. 


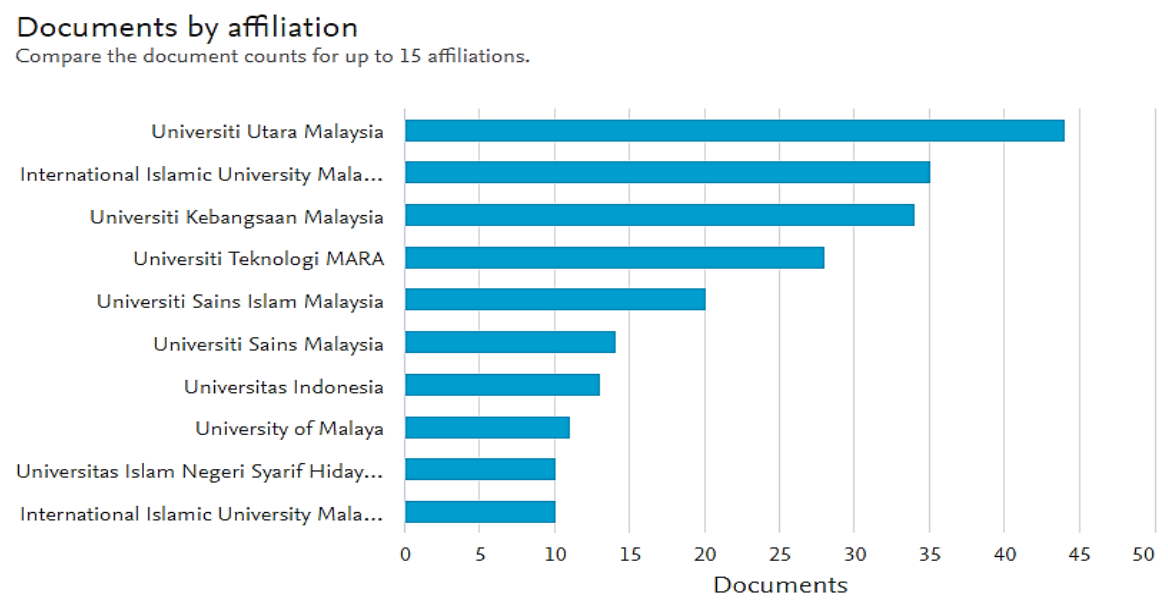

Figure 4. Screenshot of Scopus Documents by Affiliation.

The graph shows the documents by affiliation, as shown in Figure 4 below. The highest documents by affiliation are from Universiti Utara Malaysia with 44 documents. Next, the second-highest from International Islamic University Malaysia with 35 documents. Meanwhile, the thirdhighest is from Universiti Kebangsaan Malaysia with 34 documents. In addition, for the fourth-highest are from Universiti Teknologi MARA with 28 documents, and the fifth-highest are from Universiti Sains Islam Malaysia with 20 documents. Moreover, for other documents by affiliation has not more than 15 documents which are from Universiti Sains Malaysia with 14, Universitas Indonesia with 13 documents, the University of Malaya with 11 documents, Universitas Islam Negeri Syarif Hidayatullah Jakarta, and the lowest documents by affiliation are International Islamic University Malaysia, Institute of Islamic Banking and Finance with ten documents.

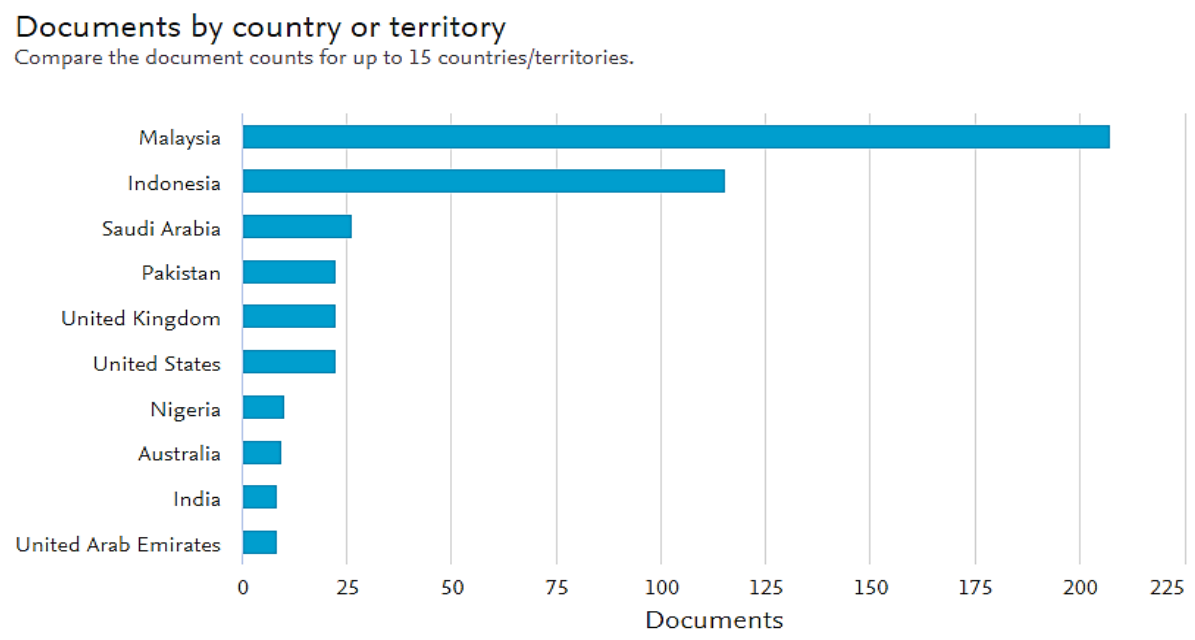

Figure 5. Screenshot of Scopus Documents by Country or Territory

Figure 5 shows the documents by country or territory. The highest documents by country or territory come from Malaysia with 209 documents. Next, the second-highest from Indonesia with 115 documents. 
Meanwhile, the third-highest is from Saudi Arabia, with 26 documents. In addition, the fourth-highest are from Pakistan with 22 documents. Also, the fifth-highest are from the United Kingdom and the United States with 22 documents. Moreover, for other documents by country or territory has not more than 10 document, which is Nigeria with ten documents, Australia with nine documents. Lastly, the lowest documents by country or territory are India and the United Arab Emirates, with eight documents.

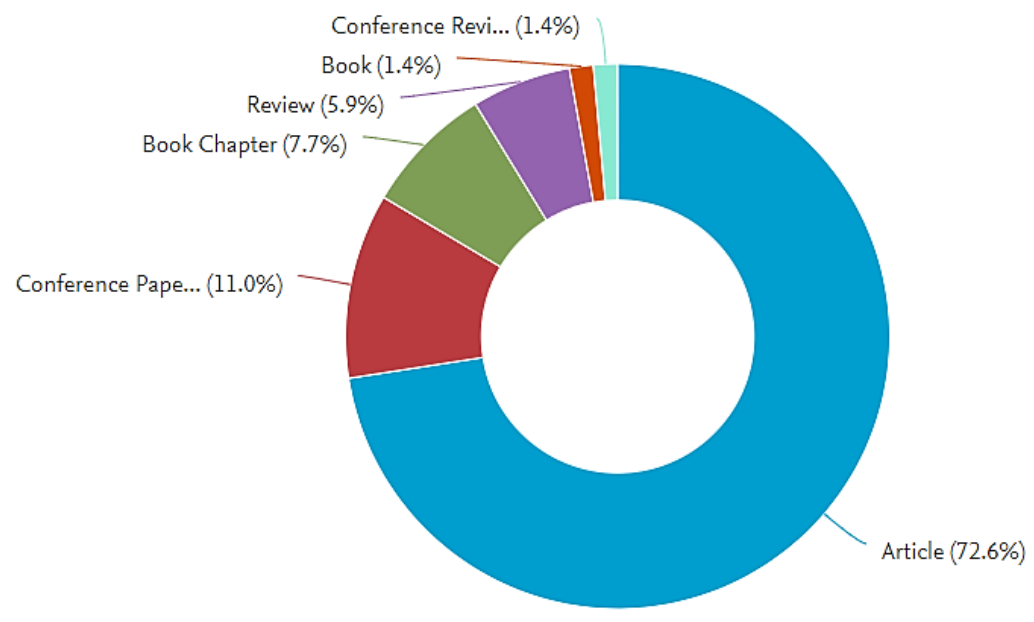

Figure 6. Screenshot of Scopus Types.

Figure 6 shows the documents by types. The result shows six types of documents, which are Article, Conference Paper, Book Chapter, Review, Book, and Conference Review. From the pie chart, it is clear that the majority of authors prefer to use an article as their sources, with 72.6 percent that has 356 documents. The second most used is Conference Paper, with 11.0 percent that has 54 documents. The third most used is Book Chapter, with 7.7 percent that has 40 documents. The fourth most use of the document by types is Review, with 5.9 percent with 29 documents. The last most used document by type is Book and Conference Review with the same percent, which is 1.4 percent with seven documents.

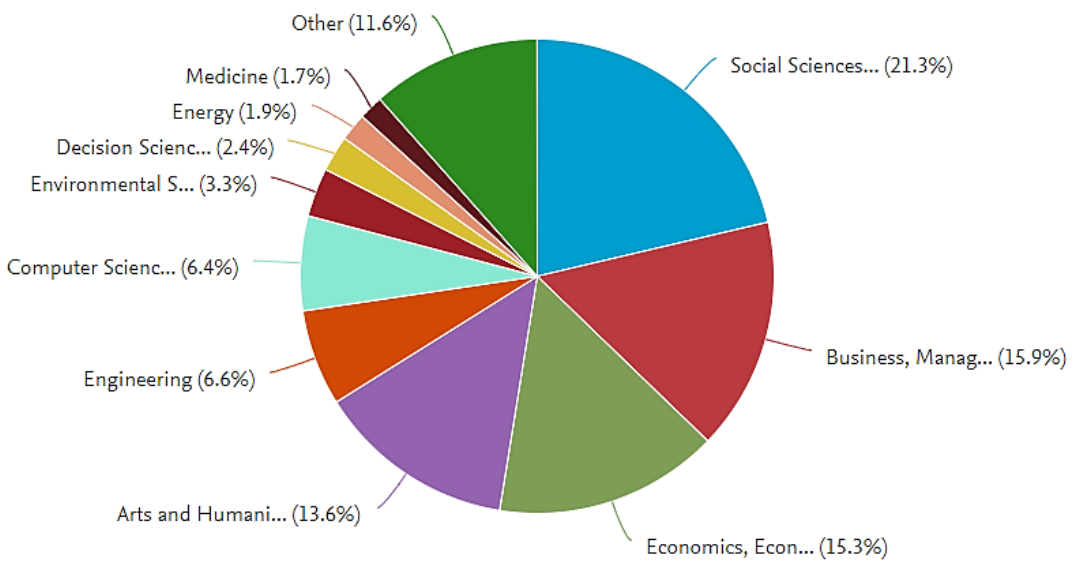

Figure 7. Screenshot of Subject Area 
Figure 7 shows the documents by subject area. The result shows eleven types of documents by subject area, which are Social Sciences, Business, Management and Accounting, Economics, Econometrics and Finance, Arts and Humanities, Engineering, Computer Science, Environmental Science, Decision Sciences, Energy and Medicine. From the pie chart, it is clear that the majority of authors prefer to use the subject area of Social Sciences, with 21.3 percent that has 195 documents. After that, Business, Management, and Accounting, with 15.9 percent, have 145 documents. Next, Economics, Econometrics, and Finance with 15.3 percent have 140 documents, and Arts and Humanities with 13.6 percent have 123 documents. Next, Engineering with 6.6 percent that has 59 documents, and
Computer Science with 6.4 percent that have 58 documents with just 1 percent difference between these two. Next, Environmental Science, with 3.3 percent that have 30 documents, and Decision Sciences with 2.4 percent, have 22 documents. Next, Energy with 1.9 percent that has 17 documents. Next, Medicine with 1.7 percent that has 13 documents and others document by subject area which is Biochemistry, Genetics and Molecular Biology, Mathematics, Physics and Astronomy, Multidisciplinary, Earth and Planetary Sciences, Materials Science, Pharmacology, Toxicology and Pharmaceutics, Agricultural and Biological Sciences, Chemical Engineering, Psychology, Nursing, Chemistry and Dentistry with 11.6 percent that has 100 documents.

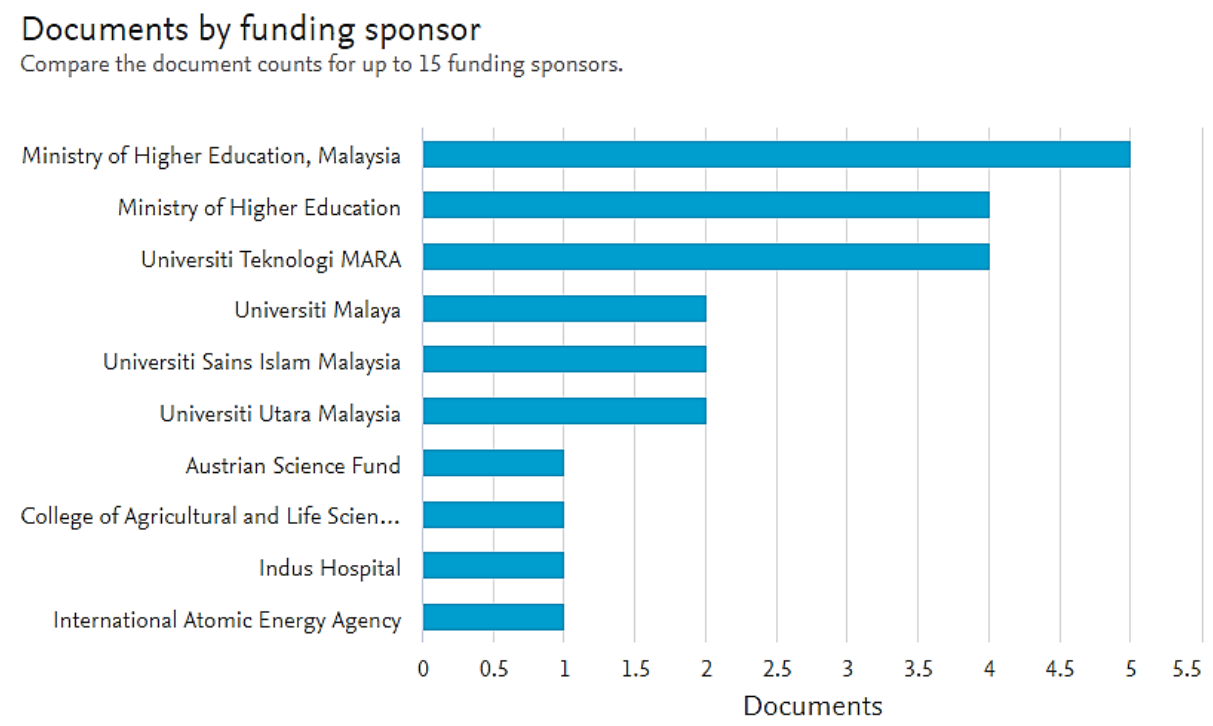

Figure 8. Screenshot of Funding Sponsor

The graph shows the documents by funding sponsors, as shown in Figure 8 below. The highest documents by funding sponsor come from the Ministry of Higher Education, Malaysia, with five documents. Next, the second-highest from the Ministry of Higher Education and Universiti Teknologi MARA with four documents.
Meanwhile, the third-highest is from Universiti Malaya, Universiti Sains Islam Malaysia, and Universiti Utara Malaysia with two documents. The last documents by funding sponsors with only one document are the Austrian Science Fund, College of Agricultural and Life Sciences, Indus Hospital, and International Atomic Energy Agency. 


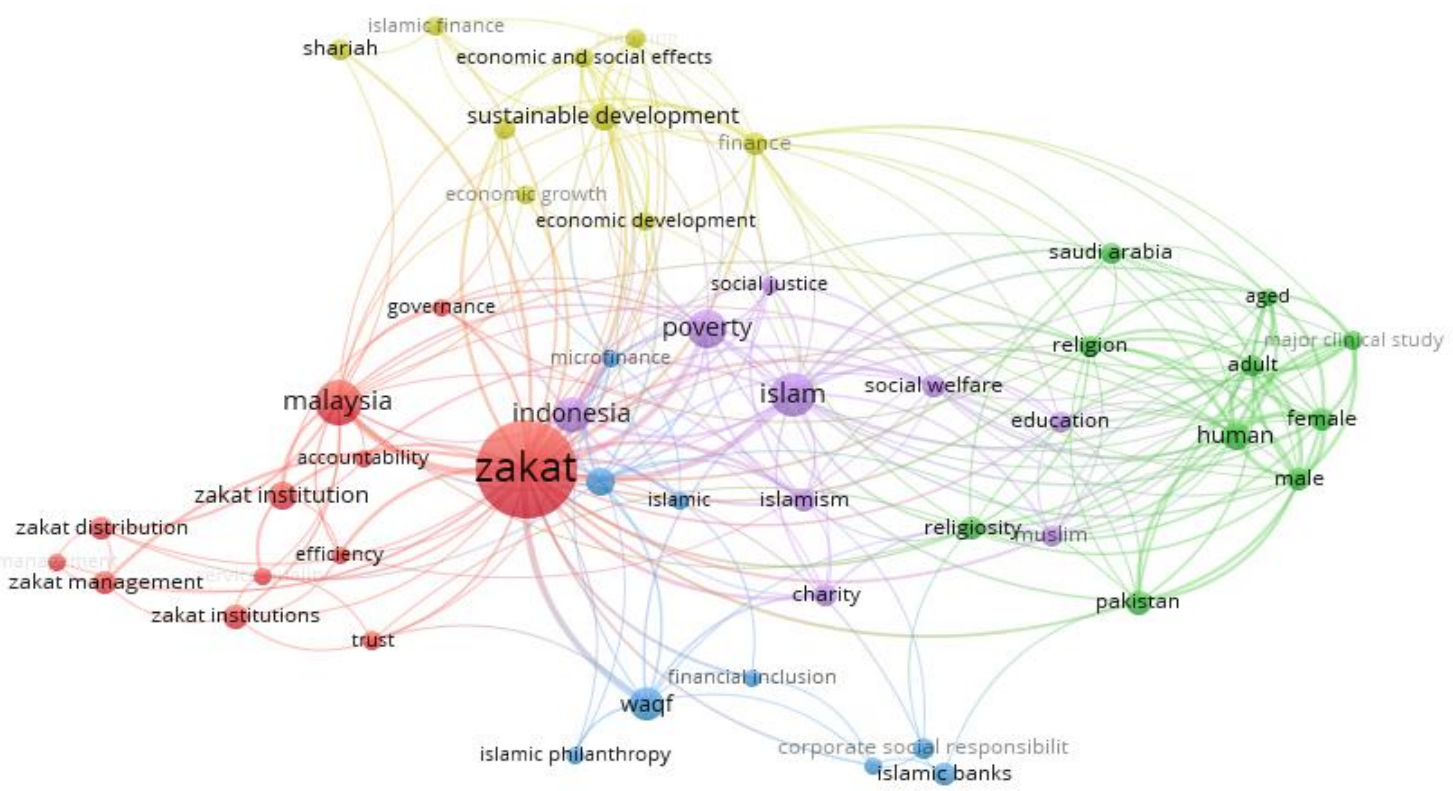

Figure 9. Vosviewer Co-Word Analysis of the Initial Retrieval Result of 493 Documents

\section{Items Divided by 5 Clusters}

Cluster 1 (12 items)
accountability
efficiency
governance
malaysia
management
service quality
trust
zakat
zakat distribution
zakat institution
zakat institutions
zakat management

Cluster 2 (10 items)
adult
aged
female
human
major clinical study
male
pakistan
religion
religiosity
saudi arabia

Cluster 3 ( 9 items)
corporate social respons
financial inclusion
islamic
islamic banks
islamic philanthropy
islamic social finance
microfinance
poverty alleviation
waqf

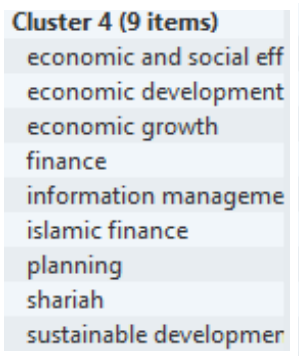

Figure 10. VOSviewer Screenshot of Using Keyword in Data Collection.

In the co-word analysis of the initial data collection VOSviewer program clustered the keywords according to similar themes (visible in different cluster colors). The result was clustered into nine numbered clusters, and the subject specialist can rename them in the analysis. Here, the result is presented according to authors' opinion as follows, Cluster 1 access control, Cluster 2 human interaction, Cluster 3 academic library, Cluster 4 processing and usage, Cluster 5 data management and analysis, Cluster 6 information retrieval, Cluster 7 e-learning, Cluster 8 information-seeking behavior, and Cluster 9 digital divide. 


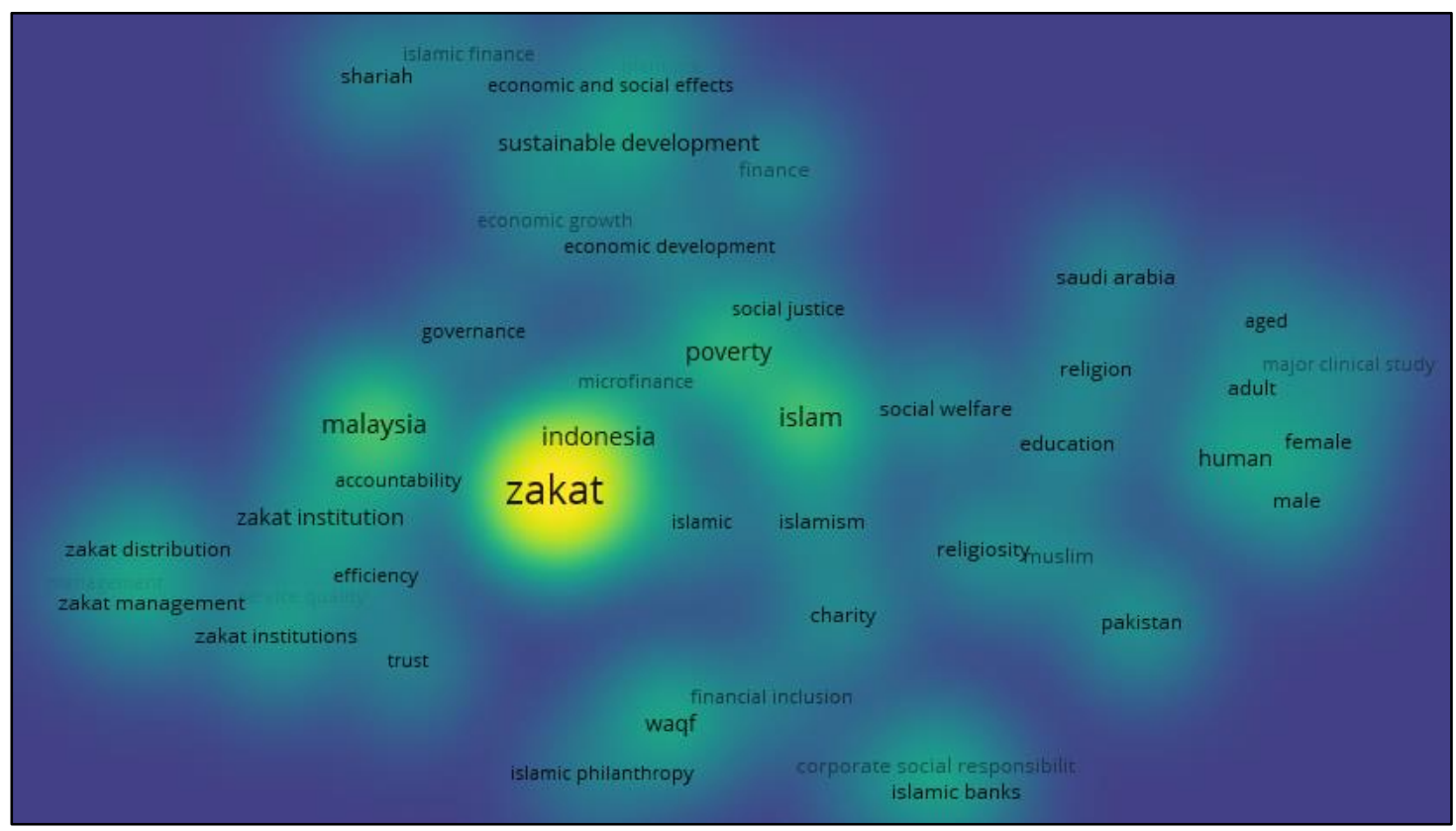

Figure 11. Co-Word Density Visualization of the Twelve High Impact Journals

In the co-word density visualization of the selected high impact journals, research on the digital library is closely related to human interaction in the form of learning and using electronic resources. Teaching and instructional technology are also related topics in digital library research. The aspect of management and processing is also an element in the subject, as shown in Figure 11.

\section{CONCLUSION}

In conclusion, this research has explored research topics in zakat in the context of zakat's usage. Results have shown that Zakat research is multidisciplinary and connected to a social phenomenon with the advent use of zakat. Nonetheless, the challenges of zakat is that although the administration of zakat has undergone many improvements in terms of infrastructure, human capital, delivery system, and governance transparency, there are still issues that need to be tackled to ensure that the administration of zakat is moving on the right track, henceforth to eradicate poverty and to upgrade people's standard of living nationally and internationally.

\section{ACKNOWLEDGEMENT}

Access to the Scopus database was provided by Perpustakaan Tunku Abdul Razak, Universiti Teknologi MARA Malaysia, Shah Alam and Ministry of Higher Education, Malaysia.

\section{REFERENCES}

Alzahrani, A. I., Mahmud, I., Ramayah, T., Alfarraj, O., \& Alalwan, N. (2019). Modelling digital library success using the DeLone and McLean information system success model. Journal of Librarianship and Information Science, 51(2), 291-306. https://doi.org/10.1177/09610006 17726123

Brahaj, A., Razum, M., \& Hoxha, J. (2013). Defining digital library. 
Lecture Notes in Computer Science (Including Subseries Lecture Notes in Artificial Intelligence and Lecture Notes in Bioinformatics), 8092 LNCS, 2328. https://doi.org/10.1007/978-3642-40501-3_3

Elisabetta, R., Macari, G., Massimo, S., Sofia, B., \& Giuseppe, S. M. (2019). Structural trend and conceptual evolution of research on genetically modified organisms using a science mapping approach. Journal of Cleaner Production, 205, 329-338. https://doi.org/10.1016/j.jclepro.2 018.09.118

Elsevier BV (2019). Scopus - Advanced search. https://www-scopuscom.ezaccess.library.uitm.edu.my /search/form.uri?display=advance $\mathrm{d} \&$ origin $=$ searchbasic \& $\mathrm{tx}$ Gid $=\mathrm{b} 6$ 5fca77e2b9f4650a6a91b569c7a5c $\mathrm{e}$

Elsevier. (2019). The largest database of peer-reviewed literature Scopus | Elsevier Solutions. https://www.elsevier.com/solution s/scopus

Geng, Y., Chen, W., Liu, Z. Z., Chiu, A. S. F., Han, W., Liu, Z. Z., Zhong, S., Qian, Y., You, W., \& Cui, X. (2017). A bibliometric review: Energy consumption and greenhouse gas emissions in the residential sector. Journal of Cleaner Production, 159(800), 301-316. https://doi.org/10.1016/j.jclepro.2 017.05.091

Jones, S., Cunningham, S. J., Mcnab, R., \& Boddie, S. (2000). Humancomputer interaction for digital libraries A transaction log analysis of a digital library. 152169.

Muhsin Nor Paizin. (2014). Pelaksanaan Zakat di Wilayah Persekutuan:
Satu Pemerhatian Terhadap Operasi Kutipan \& Agihan. Jurnal Hadhari 6 (2) (2014), 97111.

Muhsin Nor Paizin \& Suhaili Sarif. (2016). Kemudahan Pembayaran Zakat: Tinjauan Di Wilayah Persekutuan dan Selangor. Labuan e-Journal of Muamalat and Society Vol. 10(2016), 66-76.

Roldan-Valadez, E., Salazar-Ruiz, S. Y., Ibarra-Contreras, R., \& Rios, C. (2018). Current concepts on bibliometrics: a brief review about impact factor, Eigenfactor score, CiteScore, SCImago Journal Rank, Source-Normalised Impact per Paper, H-index, and alternative metrics. Irish Journal of Medical Science. https://doi.org/10.1007/s11845018-1936-5

SCImago. ( 2019). Scimago Journal \& Country Rank. https://www.scimagojr.com/

Yusuf, A.O., Yerima, B., Ape, G. (2020). Evalution of Development in Zakat Literature: A Scientometrics Analysis. International Journal of Zakat Vol. 5(1), 29-43.

Siti Maziah Ab Rahman

Universiti Teknologi MARA Cawangan Kelantan

Khalid Abdul Wahid

Universiti Teknologi MARA Cawangan Kelantan

Mohd Noor Azam Nafi

Universiti Teknologi MARA Cawangan

Kelantan

Suryani Awang Universiti Teknologi MARA Cawangan Kelantan 
Mariam Setapa

Universiti Teknologi MARA Cawangan

Kelantan

Muhsin Nor Paizin

Akademi Zakat (AZKA), Pusat

Pungutan Zakat (PPZ-MAIWP) 
